\title{
EVALUATION OF GROWTH IN ATLANTIC WHITE SHRIMP LITOPENAEUS SETIFERUS (LINNAEUS, 1767) JUVENILES, USING BIOFLOC AS A FOOD SOURCE IN A CONTROLLED ENVIRONMENT
}

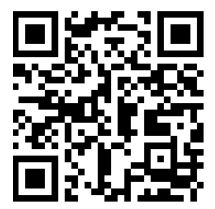

\author{
Eduardo Alfredo Zarza Meza *1凶${ }^{*}$, Jonathan Gómez Mundo 1, Rodrigo Cuervo \\ González ${ }^{1}$ \\ ${ }^{* 1}$ Facultad de Ciencias Biológicas y Agropecuarias, Poza Rica-Tuxpan Región, Universidad \\ Veracruzana, Carr. Tuxpan-Tampico Km. 7.5, Tuxpan, Veracruz, México, C. P. 92850, Tuxpan de \\ Rodríguez Cano, Veracruz
}

DOI: https://doi.org/10.29121/ijetmr.v7.i7.2020.715

Article Citation: Eduardo Alfredo Zarza Meza, Jonathan Gómez Mundo, and Rodrigo Cuervo González. (2020). EVALUATION OF GROWTH IN ATLANTIC WHITE SHRIMP LITOPENAEUS SETIFERUS (LINNAEUS, 1767) JUVENILES, USING BIOFLOC AS A FOOD SOURCE IN A CONTROLLED ENVIRONMENT. International Journal of Engineering Technologies and Management Research, 7(7), 89-96.

https://doi.org/10.29121/ijetmr.v7 i7.2020.715

Published Date: 31 July 2020

Keywords:

Biofloc

Shrimp

Sustainable

Aquaculture

Parameters

Fertilization

\section{ABSTRACT}

Biofloc is a new system, little known or applied in Mexico, that offers a high level of sustainability for aquaculture due to its great versatility in terms of nutrient recycling, which enables savings in feed costs and a significant reduction in water exchange. With the objective of evaluating the results of the use of Biofloc in aquaculture, a simulation of an aquaculture facility using Biofloc culture techniques was conducted under controlled laboratory conditions. The use of a combination of shrimp feed and refined sugar as a carbon source enabled the development of floccules, not only enabling the identification of those high-performing organisms and their development in the medium, but also facilitating shrimp capture in order to evaluate growth during each treatment. The treatments were undertaken in two different culture media, one in brackish water and the other in seawater, in which the length and weight of the animals was measured, with their behavior during the bioassay also recorded. It was found that the brackish medium enabled better shrimp development than the seawater medium, provided that the parameters and material in suspension are kept at stable levels, with the former medium providing shrimp an environment rich in food and free of pathogens.

\section{INTRODUCTION}

The Atlantic white shrimp, Litopenaeus setiferus, is a crustacean widely distributed in the Gulf of Mexico and of great commercial and aquacultural importance, making it one of Mexico's main fishery resources for export, with the United States, Japan, and Spain comprising its main markets (Arenas, 2006). In terms of total catch volume, it is the third largest fishery in the Gulf of Mexico.

Shrimp catches have been falling in the last 25 years, making the search for alternatives that would minimize the impact on the species a matter of the utmost importance not only for shrimp conservation but also to fulfil increasing economic and dietary supply and demand (CONAPESCA, 2012).

(C) 2020 The Author(s). This is an open access article distributed under the terms of the Creative Commons Attribution License, which permits unrestricted use, distribution, and reproduction in any medium, provided the original author and source are credited. 
Evaluation of Growth in Atlantic White Shrimp Litopenaeus Setiferus (Linnaeus, 1767) Juveniles, Using Biofloc as a Food Source in a Controlled Environment

Biofloc, a technique of great use for optimizing shrimp culture, involves the flocculation of nutrients (biofloccules) as a feeding system (De Schryver, 2008).

The system functions via the degradation of ammonium, which is assisted by a carbohydrate that acts as an accelerator of the nitrogen cycle, causing microbial proliferation in the medium and generating a live high-protein feed for shrimp culture. This enables the recycling of large bodies of residual water, in turn improving control over both sediment management and the nutritional requirements for aquaculture feed (Ferreira, 2014).

Catches of this crustacean have decreased in the waters of the state of Veracruz, with the 1,137-ton catch registered in 2011 indicating a 32\% reduction on the 1,659-ton catch registered in 2010, leading to a ban on the fishing of this species in order to regulate its overexploitation (CONAPESCA, 2012).

The underdeveloped nature of aquaculture in the state of Veracruz has seen decreased production, with annual production falling from 105,691 to 79,268 tons between 2002 and 2011 . This decrease is especially marked for shrimp farming, with data showing that, in 2011, shrimp farming in the state of Veracruz produced only seven tons of live weight of shrimp, with a commercial value of $\$ 437,000$ pesos. The same year, the state of Tamaulipas registered a live weight production of 2,068 tons with a commercial value of 96,018,000 pesos (CONAPESCA, 2012).

Biofloccules are formed by a mixture of waters with high ammonium, nutrient, nitrate, and nitrite content. They are converted into a type of microbial microfauna fit for consumption by animals in aquaculture. The $\mathrm{C} / \mathrm{N}$ ratio of a carbon source, which could be sugar, molasses, or another element, accelerates the nitrogen cycle, supplying the nitrifying bacteria that degrade the ammonium into its simplest particles, thus enabling the development of microbial life in the medium (Ekasari, 2010).

The tilapia Oreochromis aereus is able to easily digest flocculated feed, which can provide up to $50 \%$ of the required protein in its diet (Avnimelech, 2007). Dibello and Dassans (2013) studied both the common carp (Cyprinus carpio) and Carassius (Carassius auratus) in intensive systems using the Biofloc method, a biological filter, and a method of water control and exchange similar to a conventional aquaculture system. They obtained better results with the Biofloc method than with the other systems applied, as well as savings in terms of both feed and water exchange. Furthermore, Sáenz (2013), in research conducted on the use of the Biofloc method on tilapia fingerlings with wheat bran as a carbon source, obtained tilapia reproduction with a global survival rate of $85 \%$. Research conducted on shrimp has found that floccules can be used as a primary feed source, bringing with it savings in artificial feed costs and improvements in water quality (Martínez., 2009).

It has been found that the use of floccules as a feed source and molasses as a carbon source in the farming of Penaeus monodon shrimp with zero water exchange achieves significant results in terms of ammonia and nitrite elimination, further to improved growth and weight gain in study subjects (Panjaitan, 2010).

Nutrients synthetized via the use of bacterial activity and a sugar enable the re-assimilation of proteins, in which microorganisms fulfil a principal function in the development of both primary production and the nutrient cycle, degrading inorganic nitrogen. In research on juveniles of the species Farfantepenaeus paulensis, Ballester et al (2010) show that the dynamic presence of microorganisms and bacteria facilitates a sustainable feed medium via Biofloc. Similarly, Emerenciano (2011) describes how F. paulensis individuals subjected to treatments with different salinity levels presented higher saline concentrations and a lower $\mathrm{pH}$ than conventional treatments, further to a lower level of dependence on processed products, such as fish meal.

\section{MATERIAL AND METHODS}

The Biofloc was prepared using two 120 lt tanks filled with 100 liters of water, one to a salinity of 35 UPS and the other to a salinity of 16 UPS, to which $10 \mathrm{~g}$ of artificial feed in pellet form was added in order to fatten the shrimp via its $35 \%$ protein and 5 gr refined sugar content.

Every two days, $10 \mathrm{~g}$ of feed pellets was added, while, every four days, $5 \mathrm{~g}$ of sugar was added, with the ammonium $\left(\mathrm{NH}_{3}\right.$ and $\left.\mathrm{NH}_{4}\right)$ concentrations then analyzed, using ammonia cyanurate and ammonia salicylate (Fig. 1) (see Table 1, in annex).

Nutritionally, different diets were implemented, the first using commercial feed, while the second used feed fertilized via the Biofloc method in brackish water, and the last used feed fertilized via the Biofloc method in seawater. 
The toxic ammonium concentration was measured in the sample via:

$$
\frac{\mathrm{Mg} / \mathrm{L} \mathrm{NH} 3-\mathrm{N} \text { x evaluation table } 1 \times 1.2}{100}=\mathrm{mg} / \mathrm{L} \mathrm{NH3}
$$

The following equation was used to determine the ammonium ion concentration in the sample:

$$
\begin{aligned}
& \mathrm{Mg} / \mathrm{L} \text { NH3 -N x (100 - evaluation table }) \text { X } 1.3=\text { mg/L NH4+ + } \\
& 100
\end{aligned}
$$

Two hundred and eighty-five Atlantic white shrimp juveniles were captured in December 2013, in Lake Tampamachoco, Tuxpan, Veracruz. Once they had been transported to the study location, the subjects were placed in two 102-lt-capacity fish tanks and then acclimatized for $24 \mathrm{~h}$.

When, after 30 days, the Biofloc presented an ammonia concentration below $0 \mathrm{ml} / \mathrm{l}$, the juvenile shrimp, with an average weight of $0.8 \mathrm{gr}$ and an average length of $52.1 \mathrm{~mm}$, were introduced to three 102-lt-capacity fish tanks.

The tanks contained different salinity levels, one containing brackish water, at 16 UPS, and the second containing seawater, at 33 UPS, while the last tank contained brackish water, at 16 UPS, but without Biofloc. Twenty shrimp, subject to fasting in the 24 hours prior to their introduction to the Biofloc and with an average weight of $0.8 \mathrm{gr}$ and an average length of $52.1 \mathrm{~mm}$, were placed in each tank.

The water was kept in constant motion in order to avoid the accumulation of activated sludge, which would have caused both the death of the floccules in the tanks and the presence of anoxia, while aquarium aerators were used to keep the organic material suspended in the medium and oxygenate the Biofloc.

During the L. setiferus juveniles' development, their physicochemical parameters were recorded, as were their length, the number of organisms, and the evolution of the microfauna community present in the Biofloc.

\section{RESULTS}

The growth results obtained with the commercial feed reveal that the shrimp population fell until arriving at zero (figures 16 and 17), while those subjects that had been fed on the Biofloc-based diets presented gradual increases in weight (Figure 16) (ANOVA F20, 76=4.77, P= P <<0.001) and length (Figure 17) (ANOVA F20, 76=2.20, $\mathrm{P}=0.00751$ ). These findings reveal significant differences between the brackish and seawater treatments.

The total number of organisms present in the Biofloc over the course of the present study shows that 14 of 20 individuals, or $70 \%$ of the total initial population, remained alive at the end of the brackish water treatment, while eight juveniles survived the seawater treatment, corresponding to a survival rate of $40 \%$. As the treatment without Biofloc did not present survivors from $8^{\text {th }}$ February 2014 onwards, the treatments in brackish water presented better results than the other two treatments applied in the present study.

The Biofloc results revealed significant differences among treatments (ANOVA F1, 15=2.2916, $\mathrm{P}=0.15086$ ), while Figure 21 (ANOVA F15, 15=17.337, $\mathrm{P}<<0.001$ ) shows differences among the dates sampled, which indicate microbial growth from the beginning of the treatments up to their completion. 
Evaluation of Growth in Atlantic White Shrimp Litopenaeus Setiferus (Linnaeus, 1767) Juveniles, Using Biofloc as a Food Source in a Controlled Environment

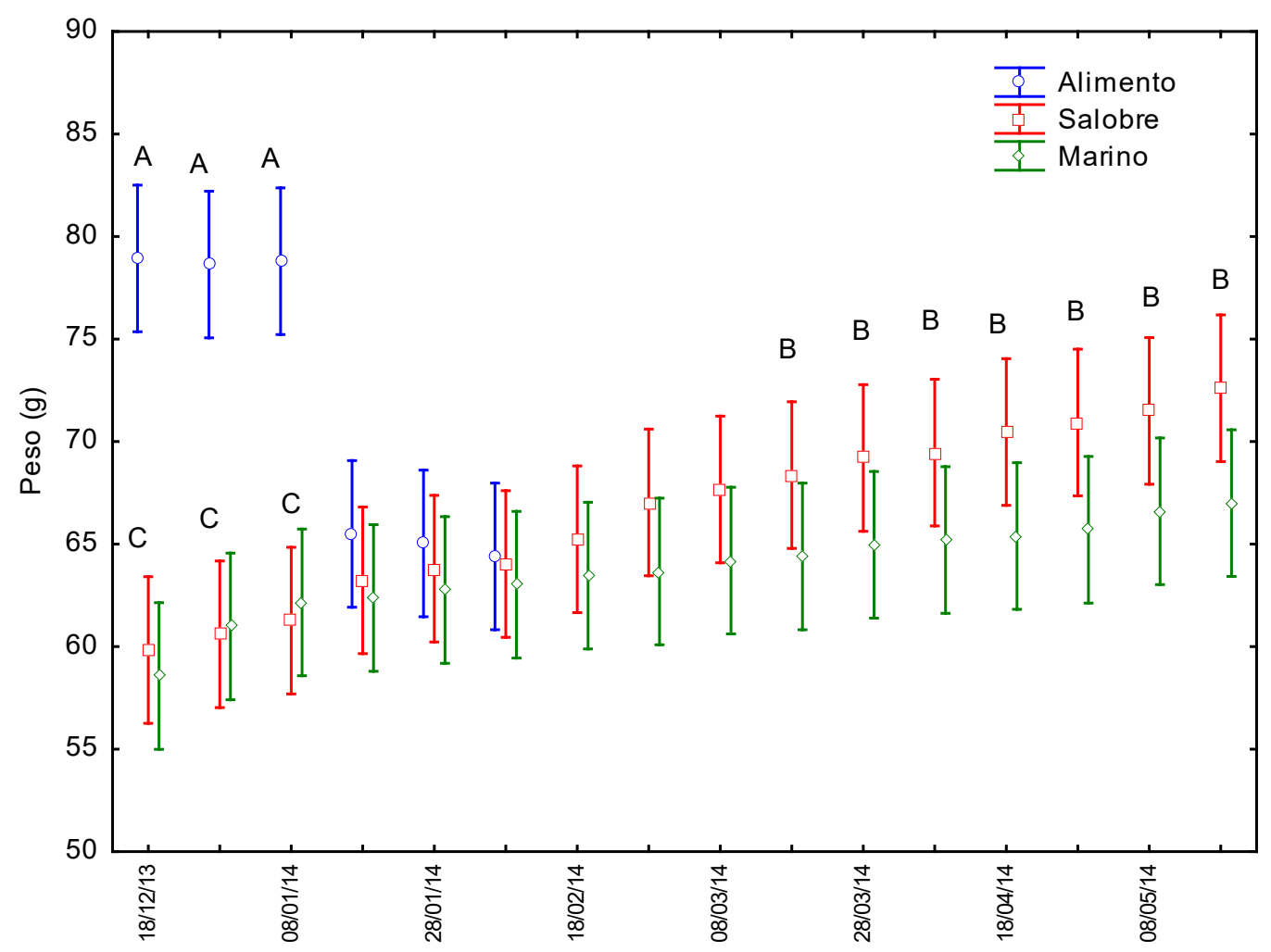

Figure 16: Factorial Analysis of Variance (ANOVA) for the data pertaining to weight (median \pm e.e.) for $L$. setiferus shrimp under the three treatments. The different letters indicate statistically significant differences.

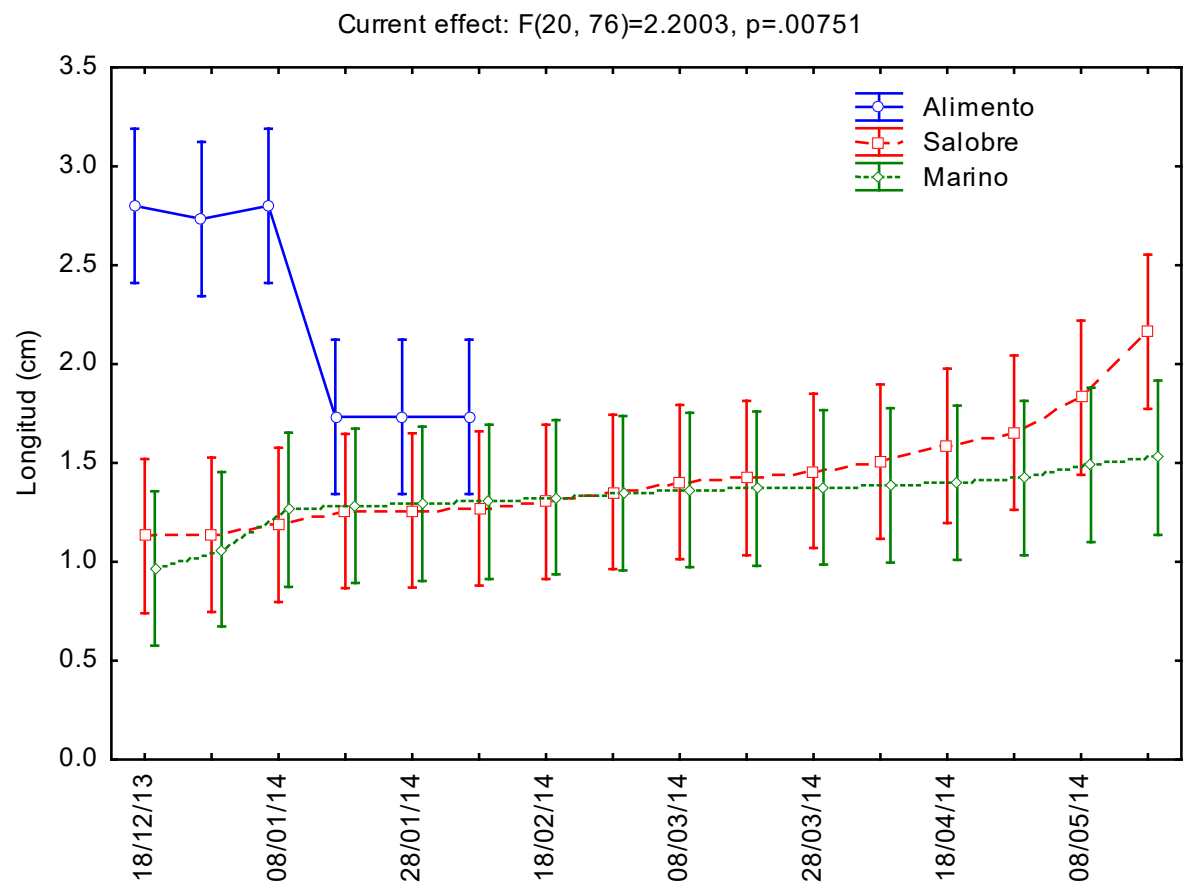

Figure 17: Significant differences observed per day sampled in the growth of the shrimp during the treatments.

Significant differences were identified between the seawater and brackish water treatments (ANOVA F1, $23=130.37, \mathrm{P}<<0.001 ;$ ANOVA F23, 23=7.7975, P<<0.001, respectively). 
Eduardo Alfredo Zarza Meza, Jonathan Gómez Mundo, and Rodrigo Cuervo González

\section{DISCUSSION}

Raising salinity by 5\% of its original level may cause processes indicating lethargy, a finding supporting the notion that juvenile shrimp undergo difficulties in adapting to seawater (Martínez, 2010) and which, thus, makes salinity an important factor in the development of Biofloc, as it influences juvenile shrimp growth. Cervantes (2011) observed that a salinity level of over 35 UPS negatively impacts the organisms' metabolism, altering their growth, which is supported by the findings of the present study, where, at a salinity of 35 UPS, there were eight individuals by the end of the experiment, while 14 individuals survived at a salinity of below 22 UPS.

In the present study, the pH ranged from 8.3 to 8.4; however, Cuellar (2010) indicates that pH margins must remain between 7 and 8 in order to avoid damaging the shrimp culture. López et. al (2012) found a pH of over 8.5 in Lake Tampamachoco in the community of La Mata in Veracruz, the location where the shrimp subject to the present research were captured, indicating greater resistance to higher pH levels. Martínez (2010) describes a pH of 7.8 to 8.3 as permissible for shrimp farming.

A broad relationship has been found between pH concentration and ammonium. Pertuz (2013) states that these peaks in ammonium concentration and $\mathrm{pH}$ are equally visible and indicate both a high level of bacterial productivity in the Biofloc, with these bacteria degrading ammonium into assimilable nitrogen, and the displacement of algae by the heterotrophic community. This may explain the sudden appearance of organisms during the early stages of the culture.

The temperature was kept at $18^{\circ} \mathrm{C}$ to $25^{\circ} \mathrm{C}$ and may have influenced the development of the shrimp, as, according to Emerenciano $(2011,2012)$, for good shrimp development, the temperature must not fall below $25^{\circ} \mathrm{C}$. However, Martínez (2010) shows that acceptable sizes in tropical shrimp species are possible at temperatures of 20 to $30^{\circ} \mathrm{C}$. The present study, conducted with the shrimp species L. setiferus, found that low temperatures were a factor negatively affecting shrimp growth throughout the research.

In the first days of the experiment, oxygen levels remained below $2 \mathrm{ppm}$, due to the great oxygenation demand of the Biofloc. Fenucci (1988) recommends an oxygenation of 5-6 ppm for shrimp farming in order to maintain the vitality of the organisms in the culture and, while this condition was able to be established in the present study, the seawater treatment presented a dissolved oxygen concentration lower than the brackish water treatment. This occurred due to the failure to take into account a factor identified by both Kjerfve (1986) and Cervantes (2011), namely that a greater concentration of dissolved salts in water is an obstacle to the absorption of other solutes in the medium, in this case dissolved oxygen. This effect was visible in the seawater treatment applied in the present study, in which the density of salts was higher, which resulted in a greater oxygenation effort.

With regard to the use of carbon sources, the present research used refined sugar for the formation of floccules, while some authors, such as Ebeling (2006), recommend the use of molasses or even yuca as a sucrose in the preparation of the flocculated medium. Ballester et al (2010) suggest molasses as the best carbon source for the formation of Biofloc, obtaining a reduction in the ammonium level in two weeks, while Pertuz (2013) promotes the use of starch, obtaining a reduction in the ammonium level in 20 days.

The use of refined sugar may have the same potential for reducing ammonium levels, enabling a $2 \mathrm{ml} / \mathrm{l}$ to $0 \mathrm{ml} / \mathrm{l}$ reduction over the same two-week period.

Maintaining control over the ammonium concentration in the Biofloc enabled a healthy medium/environment and, thus, optimal development for the shrimp, with peaks of high ammonium concentration found during the early stages of maturation, which then fell and remained at $0 \mathrm{ml} / \mathrm{l}$ for both treatments. In accordance with Panjaintan (2010), the ammonium levels presented an accelerated increase in the early stages of floccule development and then fell to zero as a result of the effect of carbon on the mixture (Emerenciano, 2012).

During the maturation of the medium, a change in coloration was observed, which coincides with the peaks in ammonia concentration and the displacement of autotrophic material.

In both treatments, which used different salinity levels, the diversity of microfauna species evolved differently, where the seawater treatment presented a greater diversity of organisms than the brackish water treatment. However, the former presented a slow population growth in contrast with the latter's high level of population growth throughout the project, among which, the presence of organisms, such as gastrotrichs, ciliates, nematodes, paramecium, platyhelminths, and rotifers, is highlighted. In terms of the organisms present in the medium, Ballester et al (2010) cite the presence of ciliates, flagellates, cyanobacteria, rotifers, and nematodes in the medium, although the nematodes only survived for the first 30 days of the test, showing these organisms to be agents harmful to the 
culture. However, Morales and Cuéllar (2008) also state that the presence of nematodes in the medium may indicate a system containing pathogenic agents that could compromise the culture and promote an environment harmful to human health. A greater diversity of organisms was found for the seawater treatment group than for the brackish water group. However, a slower population growth was observed in the former than in the latter, which presented a high level of growth in its population throughout the entire project, with the presence noted of organisms, such as gastrotrichs, ciliates, nematodes, paramecium, platyhelminths, and rotifers. In contrast, Cedano et al (2013) and Hargreaves (2013) describe the presence and use of nematodes, added to the gastrotrichs and certain chlorophyta that complement the diet used in aquaculture, while Martínez (2010) states that controlled nematode populations in the diet are beneficial for penaeid culture. The seawater treatment applied in the present study developed a higher level of nematodes throughout the formation of the floccules, in contrast with the Biofloc formed in brackish water, which presented a lower level of nematodes and only in certain stages of the culture. Further and more detailed research is required in order to determine the species and concentrations suitable for the prevalence of this organism in Biofloc.

No organisms were found in good health, namely in a state of vitality and without any other factor that would slow the appearance of disease in the culture, such as: opacity or weakness in the chitinous shell; irritation; or, decalcification. Megahead (2010) cites these factors as health indicators for shrimp. Pertuz (2013) mentions that the presence of pathogens depends on the correct balance between nutrients and the carbon source, as well as the correct oxygenation of the water, an adequate flow, and constant material in suspension in order to keep the system balanced.

\section{CONCLUSIONS}

The data obtained, in the present study, via the application of the Biofloc method with the species L. setiferus reveal that the best weight and length results were achieved via the brackish water treatment. This treatment presented an initial average weight and length of 0.8 gr and $52.1 \mathrm{~mm}$, respectively, and a final average weight and length of 2.5 gr and $73.2 \mathrm{~mm}$, respectively, after five months.

In terms of the physicochemical factors, the most stable values were found for the brackish water treatment, with these factors the main indicators for the growth rates and prevalence of individuals in the seawater and brackish water treatments.

The most notable results in terms of the survival of the individuals with the use of Biofloc were obtained in the brackish water medium, with a final survival rate of $70 \%$, which is equivalent to 14 of the 20 individuals with which the study began.

Of the two treatments, the brackish water treatment achieved better results in terms of the microbial community, presenting a larger microorganism population corresponding to concentrations of over $80,000 \mathrm{org} / \mathrm{ml}$. This treatment obtained a superior quality of organisms usable as live shrimp feed, as well as better results in terms of the degradation of said organisms. Moreover, the presence and posterior displacement of pathogenic agents, enabled by the predomination of heterotrophic agents in the Biofloc culture, is also highlighted.

\section{SOURCES OF FUNDING}

None.

\section{CONFLICT OF INTEREST}

None.

\section{ACKNOWLEDGMENT}

None. 
Eduardo Alfredo Zarza Meza, Jonathan Gómez Mundo, and Rodrigo Cuervo González

\section{REFERENCES}

[1] Arenas, F. V. Biodiversidad 2006: [actualizado 14 de octubre 2013]. http://www.biodiversidad.gob.mx/especies/Invasoras/pdf/talleres/SOBRE\%20EXPLOTACION\%20PPT\%2 0ARENAS.pdf.; 2006

[2] Avnimelech, Y. Feeding with microbial flocs by tilapia in minimal discharge bio-flocs technology ponds. Aquaculture; 2007, 264(5):140-147.

[3] Ballester, E. L. C, Abreu, P.C, Cavalli, R.O, Emerenciano, M, De Abreu, L, Wasielesky JR. W. Acuaculture nutrition; 2010,16 163-172

[4] Cedano, C. M. D., Lujan, B. A., Suarez, M, H. Crianza de Oreochromis niloticus var Chitralada en sistema Biofloc en la Empresa PRODUMAR SA, Guayaquil (Ecuador). Revista Científica de Estudiantes; 2013,1(2):79-91.

[5] Cervantes, C. Efecto de la salinidad sobre algunas variables bioquímicas, inmunológicas, fisiológicas y productivas del camarón Litopenaeus vannamei cultivado experimentalmente"; 2011, Tesis de licenciatura. Instituto Politécnico Nacional. Guasave, Sinaloa, México.

[6] CONAPESCA. Anuario estadístico de acuacultura y pesca. SAGARPA. D.F.; 2012, 296 p. México. 64

[7] Cuellar, J. Manual de buenas prácticas de manejo para el cultivo del camarón blanco Penaeus vannamei. Organización del sector pesquero y acuícola del istmo centroamericano (OSPESCA) parte del sistema de la integración centroamericana (SICA). Panamá; 2010, 53

[8] De Schryver, P. The basics of bio-flocs technology. The added value for aquaculture. Aquaculture; 2008, 277(2):125-137.

[9] Dibello, R. J, C, Dassans, G. H. C.A. Crecimiento y sobrevivencia de Carpa Común (Cyprinus carpio) y Carassius (Carassius aurata) (Osteichthys, cyprinidae) en un sistema súper intensivo con la aplicación de Biofloc, comparando con sistema de filtro biológico y sistema tradicional con aireación; 2013, Tesis de Doctorado. Universidad de la Republica Montevideo, Uruguay

[10] Ebeling, J. Engineering analysis of the stoichiometry of photoautotrophic, autotrophic, and heterotrophic removal of ammonia-nitrogen in aquaculture systems. Aquaculture; 2006, 257(4):346-358. 65

[11] Ekasari, j, Roselien, C, Willy, V. Primary Nutritional Content of Bio-Flocs Cultured with Different. Organic Carbon Sources and Salinity. HAYATI Journal of Biosciences; 2010, 17 (3):125-130

[12] Emerenciano, M., Gaxiola, G., Cuzon, G. Biofloc Technology Applied To Shrimp Broodstock. The World Aquaculture Society, Baton Rouge, Louisiana, USA.; 2011, 16 (2):217-230.

[13] Emerenciano, M. Biofloc Technology (BFT): A Review for Aquaculture Application and Animal Food Industry. Licensee InTech. 20(2):1-28 FAO, NACA, UNEP, WB, WWF, 2006. Principios internacionales para el cultivo responsable del camarón; 2012, 3.

[14] Fenucci, J. Manual para la cría de camarones peneidos FAO departamento de pesca; 1988, pg.3. http://www.fao.org/docrep/field/003/AB466S/AB466S00.htm

[15] Ferreira, S. G. Flocus microbianos como fonte de baterías prebióticas para o cultivo de Litopenaeus vannamei; 2014, Tesis de Maestría, Universidade Federal de Santa Catarina Centro de Ciencias Agrarias Departamento de aquicultura Programa de Pos-Graduacao em Aquicultura, Florianópolis.

[16] Hargreaves, J. Biofloc Production Systems for Aquaculture. Southern Regional Aquaculture Center. SRAC Publication; 2013, 45 (3):1-10.

[17] Kjerfve, B. Comparative oceanography of coastal logons; 1986, 63-81. Academic Press, Inc. (ed) For Marine Biology and coastal research. Columbia, South Carolina

[18] López, O. M., Pulido, F. G., Serrano, S.A., Gaytan, O.J.C., Monks, S. W. S., López, J. M. A. Evaluación estacional de las variables fisicoquímicas del agua de la Laguna de Tampamachoco, Veracruz, México. Revista Científica UDO Agrícola; 2012, 12 (3):713-719.

[19] Martínez, Córdova. L.R. Cultivo de camarones peneidos AGT editor. S. A. D.F.;1999, 283, México.

[20] Martínez, L. Camaronicultura mexicana y Mundial: ¿Actividad sustentable o industria contaminante? Revista Internacional de Contaminación Ambiental; 2009, 25(3):181-196.

[21] Martínez, C. L. Alimento natural en acuacultura: una revisión actualizada. Avances en Nutrición Acuícola X Memorias del X Simposio Internacional de Nutrición Acuícola Universidad Autónoma de Nuevo León, Monterrey, México; 2010, 23(3):668-699. 67 
[22] Megahead, M. E. The effect of microbial Biofloc on Water Quality, survival and growth of the green Tiger Shrimp (Penaeus semisulcatus) Fed with Different crude protein levels; 2010.

[23] Morales, Q. V, Cuellar, A. J. 2008. Guía Técnica Patología e Inmunología de Camarones Penaideos. CYTED Panama; 2008, 270.

[24] Panjaitan, P. Shrimp culture of Penaeus monodon with zero water Exchange model (zwem) using molasses. Journal of Coastal Development; 2010, 14 (1):35-44.

[25] Pertuz, V. 2013. Indicadores de calidad del floc: Interacción de los microorganismos del floc y comportamiento de las variables físico-químicas de calidad de agua en sistemas bft. Universidad de Córdoba 68 centro de investigación piscícola de la Universidad de córdoba. CINPIC. Mosquera, Colombia; 2013, 72

[26] Sáenz, V. D. Comparación de sobrevivencia de alevines de tilapia en agua fertilizada en relación carbono: nitrógeno de 9, 16 y 23; 2013, Tesis de Licenciatura. Universidad de la Republica. Montevideo Uruguay. 